\title{
GnRHR gene polymorphism and its correlation with semen quality in Buffalo bulls (Bubalus bubalis)
}

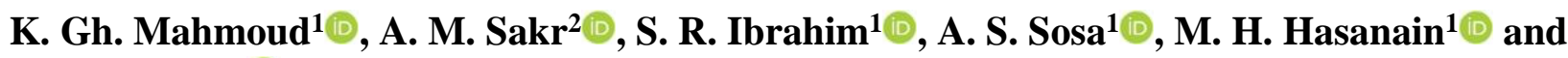 \\ M. F. Nawito' ${ }^{1}$
}

${ }^{1}$ Reproductive Genetics Lab, Department of Animal Reproduction and Artificial Insemination, Veterinary Research Division, National Research Centre, Dokki, Tahrir Street, ${ }^{2}$ Department of Biotechnology, Animal Production Research Institute, Giza, Egypt

\begin{tabular}{l} 
Article information \\
\hline Article history: \\
Received April 8, 2020 \\
Accepted June 19, 2020 \\
Available online March 15, 2021 \\
\hline Keywords: \\
Buffalo bull \\
GnRHR gene \\
Semen analysis \\
Genotyping \\
\\
\hline Correspondence: \\
K. Gh. Mahmoud \\
karimamahmoud@yahoo.com
\end{tabular}

Article information

Received April 8, 2020

Accepted June 19, 2020

Keywords:

Buffalo bul

GnRHR gene

Semen analysis

Genotyping

K. Gh. Mahmoud

karimamahmoud@yahoo.com

\begin{abstract}
Fresh semen from fifty bulls was evaluated for ejaculate volume, individual motility, concentration, lives sperm and abnormalities as well as acrosome integrity. Bulls were classified according to semen motility into two groups; good and poor. DNA was extracted from semen of both groups, then the PCR followed by single-strand conformation polymorphism (SSCP) techniques were performed for mutation detection in gonadotropin releasing hormone receptor (GnRHR) gene through multiple sequence alignment. The results showed that the percentages of sperm motility, sperm concentration and live sperm, were significantly higher in good than poor semen quality bulls. However, semen volume, percentage of acrosome integrity and abnormalities did not differ between good and poor. The PCR amplification of 240-bp fragment and the results of SSCP appeared a genetic polymorphism with two patterns. Pattern I was seen in all good bulls, with incidence of $100 \%$. Pattern II appeared only in poor semen quality bulls with a frequency of $31.25 \%$. The sequence analysis of the PCR product for the two patterns showed two single nucleotide polymorphisms (SNPs) as a transversion base substitution mutation at positions 20 (T/A) and 193 (A/T). The GnRHR gene could be used as a genetic marker related to semen quality in buffalo due to the good semen bulls had a unique pattern.
\end{abstract}

DOI: 10.33899/ijvs.2020.126886.1407, (C2021, College of Veterinary Medicine, University of Mosul.

This is an open access article under the CC BY 4.0 license (http://creativecommons.org/licenses/by/4.0/)).

\section{Introduction}

Function of gonadotropin-releasing hormone $(\mathrm{GnRH})$ is to motivate the synthesis and release of both follicle stimulating hormone and luteinizing hormone, which mange gametogenesis and steroidogenesis (1). The response of pituitary gonadotropes to $\mathrm{GnRH}$ associates with the concentricity of $\mathrm{GnRH}$ receptors (GnRHR) at the cell surface (2). GnRHR gene has effect on reproduction and the gene mutations influence sex hormone levels (3). It is outstanding that artificial insemination requires bulls with fantastic semen quality to transfer the characteristics to their offspring (4). Semen assessment has been utilized as a pointer of fertility $(5,6)$. The motility, concentration and normal sperm rate have been commonly used as judging requirements for evaluation of semen quality (7). However, direct selection for semen quality is difficult due to their low heritabilities (8). In addition, reproductive traits are co-controlled by multiple genes (9). Selective breeding is essential for improvement the bull hereditary and candidate genes are used as markers for sperm quality after the development of molecular techniques. Few investigations on GnRHR polymorphisms gene as a marker for fertility and semen quality were recorded in cattle $(10,11)$. It was a study in Chinese water buffalo recorded a significant correlation between ejaculate volume of the sperm and single nucleotide 
polymorphisms (SNPs) in the GnRHR gene (12). Recently, another study in Chinese water buffalo by Wang et al. (13) showed a significant association between the SNPs of GnRH and sperm quality. Therefore, the authors recommended the working on additional animal breeds to confirm whether the $\mathrm{GnRH}$ gene is the major gene that can influence semen qualities. However, in Egyptian buffalo bull this relation has not been explored comparing to other buffalo breeds. To date, there is no significant correlation between GnRHR polymorphisms and sperm qualities in Egyptian buffalo bulls has been conducted. Along these lines, the current work intended to investigate the genetic polymorphism of GnRHR gene and its correlation with fresh semen quality in Egyptian buffalo bulls.

\section{Material and methods}

\section{Bulls}

Fifty buffalo bulls (Bubalus bubalis) aged 3-5 years were subjected to semen assessment and genetic characterization of GnRHR gene. These bulls belonged to a breeding station at Mahalet Mussa close to Sakha, Kafr el-Sheikh Governorate, Egypt. All buffalo bulls were exposed to the same management and nutrition programs. Semen ejaculates were collected weekly for a period of 6 weeks (replicates; $n$ $=6$ ). The bulls were classified according to fresh semen motility into two groups; the first had more than $60 \%$ motility (good; $n=34$ ) and the second had lower than $60 \%$ motility (poor; $n=16$ ). Libido evaluation was based on reaction time (in seconds) which was taken by the bulls from exposure to the teaser until mounting.

\section{Semen evaluation}

Ejaculates were collected by artificial vagina at $42^{\circ} \mathrm{C}$. Each ejaculate was transferred to the laboratory rapidly and kept in a water bath at $37^{\circ} \mathrm{C}$ for performing evaluation tests. Volume of the ejaculates was assessed to nearest $0.1 \mathrm{ml}$. Individual motility was expressed as the percentage of forward motile spermatozoa. Concentrations were recorded via Neubauerhaemocytometer. Live sperm and abnormalities percentages were evaluated using eosinnigrosin stained smears (7). The percentage of acrosome integrity was assessed, by Giemsa staining (14).

\section{DNA extraction from sperm cells}

DNA was extracted chemically from fresh semen of all bulls as indicated by Weyrich (15) with some modifications. About fifty $\mu \mathrm{l}$ of semen was washed in $500 \mu \mathrm{l}$ of $70 \%$ ethanol then were centrifuged at $10,000 \times \mathrm{g}$ for $5 \mathrm{~min}$ and the supernatant was expelled. The former steps were repeated until the supernatant became clear, noticeable and a white pellet was obtained. About $500 \mu 1$ lysis buffer $(50 \mathrm{mM}$ Tris$\mathrm{HCl}$, pH 8 (Merck, Germany); $10 \mathrm{mM}$ EDTA (Sigma Aldrich, USA); $100 \mathrm{mM} \mathrm{NaCl}$ (Modern lab, Egypt); $1 \%$ SDS aqueous solution (ACROS Organics, Part of thermo
Fisher Scientific, USA) was added to the sperm pellet. Additionally, $5 \mu \mathrm{l}(0.5 \%)$ Triton-X100 (Bio-basic Canada Inc, Canada), 25 $\mu 1$ Dithiothreitol1M (Research Product International, Illinois, Chicago, USA). and $50 \mu$ l proteinase $\mathrm{K}(20 \mathrm{mg} / \mathrm{ml})$ were supplemented. The samples were mixed well and incubated overnight at $50^{\circ} \mathrm{C}$ in a thermo shaker. The tubes were centrifuged at $15,500 \times \mathrm{g}$ for $10 \mathrm{~min}$ and the supernatant was transferred into another $1.5 \mathrm{ml}$ tube. For DNA precipitation, $3 \mathrm{M}$ sodium acetate was added to the supernatant (about $1 / 10 \mathrm{Vol}$. of the supernatant) and mixed gently and cold absolute ethanol was added to the tubes (2 Vol. of the supernatant). DNA was precipitated at $-20^{\circ} \mathrm{C}$ overnight and pelleted by centrifugation for $20 \mathrm{~min}$ at 15,500 $\times \mathrm{g}$. After that, the supernatant was carefully removed by pipetting and the white pellet of DNA remained. DNA was washed by dispensing the pellet in $500 \mu 1$ ethanol (75\%). The samples were centrifuged for $15,500 \times$ gat $10 \mathrm{~min}$ then were dried until ethanol was disappeared. The DNA pellets were dissolved in $50 \mu 1 \mathrm{ddH}_{2} \mathrm{O}$ and concentration was estimated using NanoDrop1000 Thermo Scientific spectrophotometer (USA) then diluted to working concentration of $50 \mathrm{ng} / \mu \mathrm{l}$ for PCR.

\section{PCR Reaction and DNA Amplification}

The primer for amplification of 240-bp fragments of GnRHR gene was described by Milazzotto et al. (16) then Sosa et al. (17) with the following nucleotide sequence: F: AAACTACAACTGAATCAGTC and R: TAGAGAGAAATATCCATATA. Amplification reactions were done in $50 \mu \mathrm{l}$ volume, containing $5.00 \mu \mathrm{l}$ buffer 10x, $1.00 \mu 12.5 \mathrm{mM}$ (dNTPs mixture), $0.30 \mu 1$ Taq polymerase $(5 \mathrm{U} / \mu \mathrm{l}), 0.25 \mu \mathrm{l}$ primer, $3.00 \mu \mathrm{l} 25 \mathrm{mM}$ (MgCL2), 35.20 $\mu 1$ water (nuclease free water) and $5.00 \mu \mathrm{l}$ DNA sample. The PCR program was; one cycle at $95^{\circ} \mathrm{C}$ for $4 \mathrm{~min}$, and 35 cycles of the sequence: $95^{\circ} \mathrm{C}$ for $60 \mathrm{sec}, 55^{\circ} \mathrm{C}$ for $30 \mathrm{sec}$ and $72^{\circ} \mathrm{C}$ for $60 \mathrm{sec}$. Upon completion of the reaction, the products were exposed to electrophoresis in $2 \%$ agarose gel.

\section{Single strand conformation polymorphism}

PCR products of $7.00 \mu \mathrm{l}$ were mixed with $8.00 \mu \mathrm{l}$ of denaturing solution (98\% formamide; $20 \mathrm{mM}$ EDTA, $\mathrm{pH}$ $8.0 ; 0.05 \%$ xylene cyanol; $0.05 \%$ bromophenol blue). At this point, denaturation of the samples occurred by heating at $95^{\circ} \mathrm{C}$ for $8 \mathrm{~min}$, then samples were put on ice for $8 \mathrm{~min}$ and loaded in 1x TBE buffer on to12\% polyacrylamide gel consists of (37.5:1 acrylamide: bisacrylamide, $10 \mathrm{ml}$ $1 \times$ TBE buffer (Trisbase, Boric acid, $\mathrm{Na}_{2}$ EDTA), $2.5 \mathrm{ml}$ glycerol, $17.5 \mathrm{ml}$ deionized water, $400 \mu \mathrm{l}$ APS solution

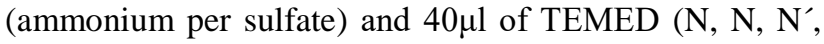
$\mathrm{N}^{\prime}$-Tetramethylethylenediamine). Electrophoresis was done at $4^{\circ} \mathrm{C}, 70 \mathrm{~V}$ for $18 \mathrm{~h}$. Silver staining technique was utilized to visualize the separated DNA-fragments with high sensitivity on polyacrylamide gels as indicated by $(18,19)$. 


\section{Sequence analysis}

The PCR products of the two patterns were sequenced by the company of Macrogen Incorporation sequencing (Seoul, South Korea). The sequence data were analyzed and alignment was performed by NCBI/BLAST/blastn suite. Single nucleotide polymorphism was analyzed using BioEdit software, through pairwise sequence alignment of two different patterns.

\section{Statistical analysis}

Data were analyzed for effect of bulls semen motility (good vs. poor) on inspected semen parameters by Student ttest using SPSS (ver. 18) statistical software. Correlation coefficient between reaction time and fresh semen parameters was determined. Differences were assumed significant at $P<0.05$.

\section{Results}

Fresh semen characteristics in good and poor semen quality buffalo bulls are appeared in Table (1). The percentages of sperm motility $(P \leq 0.001)$, live sperm $(P \leq 0.001)$ and sperm concentration $(P \leq 0.05)$ were significantly higher in good than poor semen quality bulls. However, semen volume, percentage of acrosome integrity and abnormalities did not differ between good and poor. In our investigation, the reaction time (taken by the bulls from exposure to the teaser until mounting) of good group was $43.3 \pm 1.4 \mathrm{sec}$ with no significant from poor group $(58.5 \pm 3.3 \mathrm{sec})$. Our results in table (2) detailed that reaction time had a significant negative correlation with live sperm volume ( $\mathrm{r}=-0.55, P \leq 0.03)$ in poor group and concentration
( $\mathrm{r}=-0.64, P \leq 0.01)$ in good group. Regardless semen quality, all bulls showed significant negative correlation with motility $(\mathrm{r}=-0.36, P \leq 0.05)$, volume $(\mathrm{r}=-0.36, P \leq 0.04)$ and concentration $(\mathrm{r}=-0.38, P \leq 0.03)$.

In the present study, PCR-SSCP marker was used to demonstrate the polymorphism of GnRHR gene in Egyptian buffaloes bulls and their association with semen parameter. The PCR product was 240-bp fragment of GnRHR gene (Figure 1). Allele-frequency analysis of genetic polymorphism patterns of GnRHR gene locus in Table 3 and Figure 2 revealed that pattern I was the most common compared with patterns II ( $68.75 \%$ vs. $31.25 \%$, respectively) in poor bulls. The findings of semen analysis were used as the phenotype information to classify the bulls into good and poor semen quality bulls. Accordingly, 34 animals were considered as good and 16 animals were found to be poor. Pattern I was seen in all 34 bulls, with an incidence of $100 \%$ in good bulls. Pattern II appeared in a frequency of $31.25 \%$ of poor bulls.

The sequence alignment of $205 \mathrm{bp}$ out of $240 \mathrm{bp}$ of buffalo GnRHR gene with accession number (KY786096.1) sequence was performed, by BLAST and showed that the 205 bp segment possess identities at 99\% (Figure 3). Moreover, the sequence of the same DNA segment was 99\% identities with the accession number: GenBank: EU621854.1 (Figure 4). The DNA sequence of $205 \mathrm{bp}$ of GnRHR amplified segment (240 bp) was determined. The sequence analysis of the PCR product for the two different patterns showed two SNPs as a transversion base substitution mutation at positions $20(\mathrm{~T} / \mathrm{A})$ and $193(\mathrm{~A} / \mathrm{T})$ as shown in Figure (5).

Table 1: Biophysical characteristics of fresh buffalo semen from good and poor semen quality bulls (Means \pm SE)

\begin{tabular}{lcccccc}
\hline Bulls (No. ) & $\begin{array}{c}\text { Semen volume } \\
(\mathrm{mL})\end{array}$ & $\begin{array}{c}\text { Sperm concentration } \\
\left(10^{9} / \mathrm{ml}\right)\end{array}$ & $\begin{array}{c}\text { Motility } \\
\%\end{array}$ & $\begin{array}{c}\text { Live sperm } \\
\%\end{array}$ & $\begin{array}{c}\text { Sperm } \\
\text { abnormality \% }\end{array}$ & $\begin{array}{c}\text { Acrosome } \\
\text { integrity } \%\end{array}$ \\
\hline Good (34) & $2.7 \pm 0.3$ & $1.5 \pm 0.1^{*}$ & $70.9 \pm 1.1^{* *}$ & $78.9 \pm 1.4^{* *}$ & $17.7 \pm 1.2$ & $62.5 \pm 3.4$ \\
Poor $(16)$ & $2.5 \pm 0.3$ & $1.1 \pm 0.1$ & $44.0 \pm 3.3$ & $58.6 \pm 3.4$ & $19.1 \pm 1.1$ & $56.3 \pm 2.8$ \\
\hline${ }^{*}=P<0.05$ and $^{* *}=P<0.001$ (t-Test) & & & & & &
\end{tabular}

${ }^{*}=P<0.05$ and $^{* *}=P<0.001$ (t-Test).

Table 2: Correlation coefficient (r) between reaction time and semen parameters of good and poor semen quality bulls

\begin{tabular}{lccccccc}
\hline Bulls Semen $(\mathrm{n})$ & $\mathrm{r}$ & Motility & Volume & Live sperm & Abnormalities & Acrosome & Concentration \\
\hline \multirow{2}{*}{ Good (34) } & Reaction time & .055 & $-.447-$ & .163 & $-.307-$ & $-.385-$ & $-.640^{* *}$ \\
& $P$ value & .841 & .083 & .546 & .247 & .141 & .008 \\
\multirow{4}{*}{ Poor (16) } & Reaction time & .065 & $-.297-$ & $-.547^{*}$ & .034 & .217 & .235 \\
& $P$ value & .810 & .264 & .028 & .902 & .419 & .381 \\
\multirow{4}{*}{ Good+ Poor (50) } & Reaction time & $-.357^{*}$ & $-.358^{*}$ & $-.237-$ & $-.097-$ & $-.249-$ & $-.379^{*}$ \\
& $P$ value & .045 & .044 & .191 & .598 & .170 & .033 \\
\hline
\end{tabular}

${ }^{*}=P<0.05$ and $^{* *}=P<0.001$ (t-Test). 
Table 3: Patterns and frequencies of GnRH receptors gene polymorphism in good and poor semen quality bulls

\begin{tabular}{lccccc}
\hline \multirow{2}{*}{$\begin{array}{l}\text { Bulls } \\
\text { semen }\end{array}$} & $\begin{array}{c}\text { Total } \\
\text { number of } \\
\text { animals }\end{array}$ & \multicolumn{2}{c}{ Pattern I } & \multicolumn{2}{c}{ Pattern II } \\
& 34 & 34 & $100 \%$ & 0 & $0 \%$ \\
\hline Good & 16 & 11 & $68.75 \%$ & 5 & $31.25 \%$ \\
Poor & 16 & No & $\%$ \\
\hline
\end{tabular}

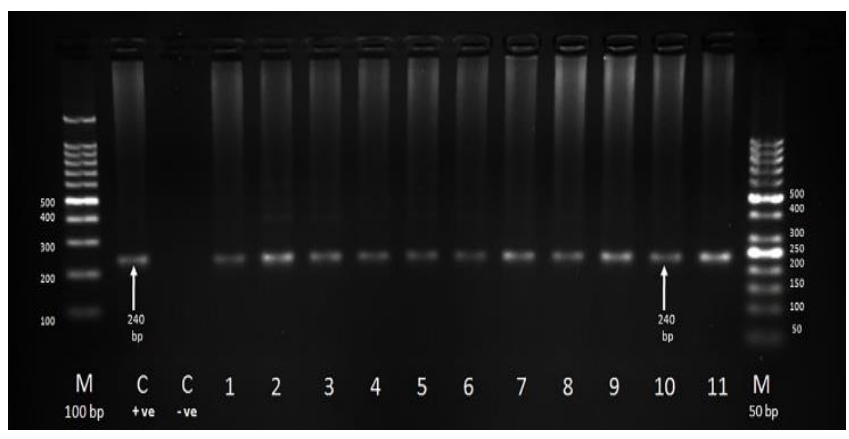

Figure 1: 240-bp PCR product of buffalo GnRHR gene stained with ethidium bromide M: 50 and 100-bp ladder.

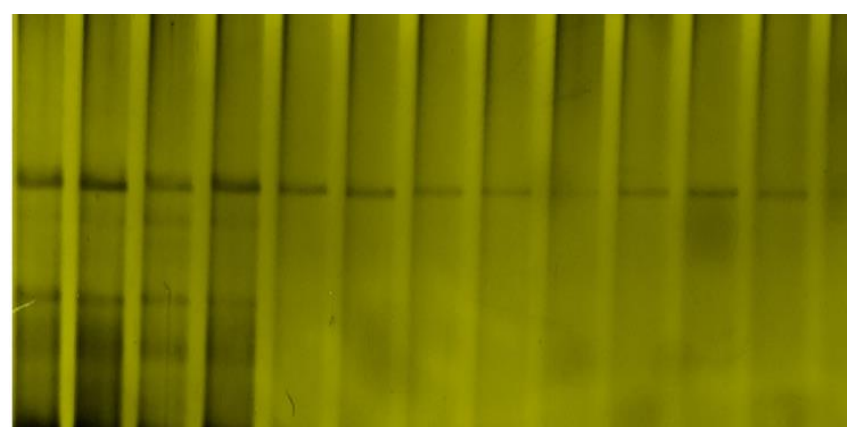

Figure 2: Two different SSCP patterns of GnRHR gene in tested Egyptian buffalo on $12 \%$ silver stainedpolyacrylamide gel. Lanes: 5-12: pattern I. Lanes: 1-4: pattern II.

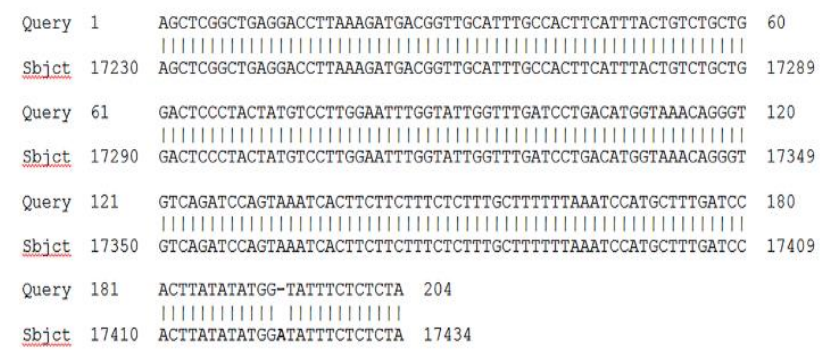

Figure 3: Sequence analysis of 205 segment of Egyptian buffalo GnRHR amplified product compared to Bubalus bubalis breed Murrah gonadotropin-releasing hormone receptor (GNRHR) gene, complete cds. Sequence ID: KY786096. 1.

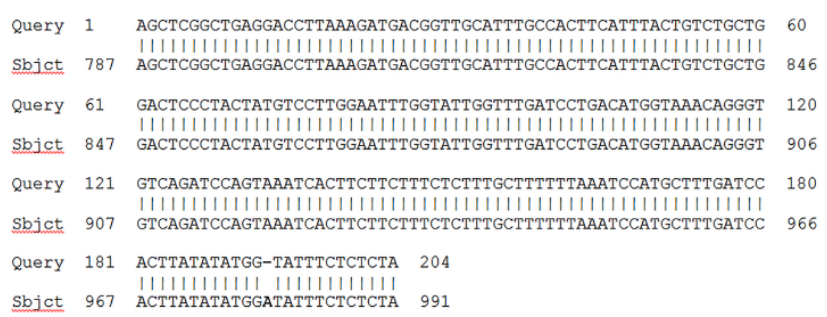

Figure 4: Sequence analysis of 205 segment of Egyptian buffalo GnRHR amplified product compared to Bubalus bubalis pituitary type-I gonadotropin releasing hormone receptor mRNA, complete cds. Sequence ID: EU621854. 1.

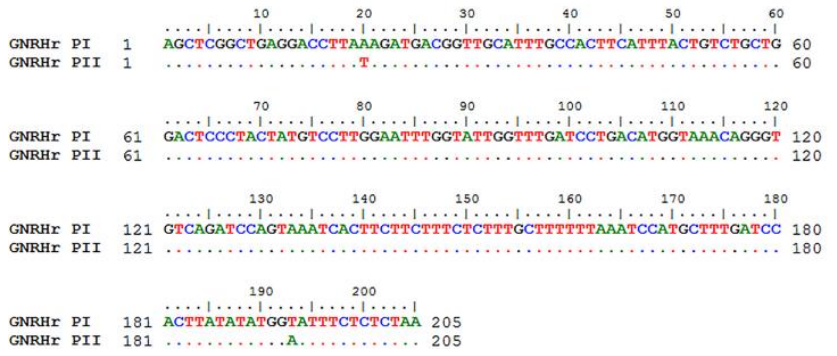

Figure 5: Pairwise sequence Alignment of two different patterns of GNRHR gene in Egyptian buffalo using BioEdit software, showing two transversion base substitution mutation.

\section{Discussion}

In the current study, the percentages of sperm motility, live sperm and sperm concentration were significantly higher in good than poor semen quality bulls. However, semen volume, percentage of acrosome integrity and abnormalities did not differ between good and poor. In accordance, many studies have recorded that bad sperm quality, leads to decrease the rate of blastocysts (20-22), and high rates of pregnancy failure (23). Moreover, (24) documented that fertility from the artificial insemination correlated with semen parameter. Motility is significant marker for semen quality as noteworthy connections between motility and both of membrane integrity and sperm abnormalities were reported (25). Likewise, correlations were present between sperm vitality and pregnancy rates (26).

In our investigation, the reaction time of good group was no significant from poor group. The two groups were scored as 3 for reaction time according to (27). The reaction time had a significant negative correlation with live sperm volume in poor group and concentration in good group. Regardless semen quality, all bulls showed significant negative correlation with motility, volume and concentration. In this regard, Moghaddam et al. (28) recorded that reaction time had a significant negative relationship $(\mathrm{r}=-0.15, P \leq 0$. 04) 
with semen volume. Singh et al. (27) stated that head abnormalities had a positive significant correlation with reaction time. In buffalo, Anzar et al. (29), found that semen production was related to sexual behavior in low categories bulls $(\mathrm{r}=0.84, P \leq 0.005)$. The correlation between libido and seminal traits confirmed the needs for simultaneous selection for both libido and semen quality in the herd (30).

In the present study, PCR-SSCP marker was used to demonstrate the polymorphism of GnRHR gene in Egyptian buffaloes bulls and their association with semen parameter. Pattern I was seen in $100 \%$ in good bulls and pattern II appeared in a frequency of $31.25 \%$ of poor bulls. In this context, another study in dairy cattle indicated that GnRHR gene can be a possible marker for refinement the sperm quality, as bulls with GA or CT genotype should be selected for breeding (10). In pig, GnRHR has been utilized as a candidate gene for semen quality, as the association of GnRHR with motility, abnormal sperm rate, and plasma droplets rate was recorded (31). Kerekoppa et al. (32) confirmed high genetic polymorphism in GnRHR gene via PCR-SSCP technique in cattle.

In our study, the sequence analysis of the PCR product for the two different patterns showed two SNPs as a transversion base substitution mutation at positions 20 (T/A) and $193(\mathrm{~A} / \mathrm{T})$. In accordance, the association between the sperm quality and SNPs in the GnRHR gene was recognized in Chinese buffalo (12). Additionally, Liron et al. (33) described bovine GnRHR polymorphisms in beef bulls and found eight SNPs of which five in the coding regions, might be responsible for the differences within bulls reach puberty. In our study, the presence of mutation in poor semen quality bulls may suggest it responsibility in lower motility. Interestingly, Sosa et al. (17) reported three nucleotide substitutions in GnRHR gene associated with ovarian inactivity in Egyptian buffaloes. So the genetic variation is needed for buffalo selection (34).

\section{Conclusions}

GnRHR gene in buffalo bulls is polymorphic with two SSCP patterns, the pattern I is characteristics for good semen quality bulls. These finding propose that GnRHR gene could be utilized as hopeful genetic marker for semen quality in buffalo bulls.

\section{Acknowledgements}

This study was funded by National Research Centre, Cairo, Egypt. Project number 1102101.

\section{Conflicts of interest}

None.

\section{References}

1. Okuzawa K, Kobayashi M. Gonadotropin-Releasing Hormone Neuronal Systems in the Teleostean Brain and Functional Significance. Kluwer Academic/Plenum, New York.1999;85-100 p. https://doi.org/10.1007/978-1-4615-4805-8_6.

2. Stojilkovic SS, Catt KJ. Expression and signal transduction pathways of gonadotropin-releasing hormone receptors. Recent Prog Horm Res.1995;50:161-205. https://doi.org/10.1016/B978-0-12-571150$0.50012-3$.

3. Sun J, Chu MX, Chen HQ. Polymorphism of GnRHR gene and its relationship with prolificacy of small tail Han sheep. J Agri Biot. 2008; 16:230-236.

http://journal05.magtech.org.cn/Jwk_ny/EN/abstract/abstract9389.sht $\mathrm{ml}$.

4. Brito LF, Silva AE, Rodrigues LH, Vieira FV, Deragon LA, Kastelic JP. Effects of environmental factors, age and genotype on sperm production and semen quality in Bosindicus and Bostaurus AI bulls in Brazil. Anim Reprod Sci. 2002;70(3-4):181-190. Doi: 10.1016/s03784320 (02) 00009-x

5. Malmgren L, Larsson K. Semen quality and fertility after heat stress in boars. Acta Vet Scand. 1984;25:425435.https://pubmed.ncbi.nlm.nih.gov/6524574/.

6. El-Sisy GA, Mahmoud KGM, El-sokary AAE, Nawito M, Ahmed YF. Factors affecting in- vivo fertility of crossbred Egyptian-Italian buffalo semen. Asian Pacific J Reprod. 2017;6(6):264-267. Doi: 10.4103/23050500.217341.

7. Hasanain MH, Mahmoud KGh M, EL-Menoufy AA, Sakr AM, Ahmed YF, and Othman OE. Semen characteristics and genotyping of pituitary-specific transcription factor gene in buffalo using PCR-RFLP. Egypt J Vet Sci. 2016;47(1):13-26. Doi: 10.21608/ejvs.2016.1079.

8. Rothschild MF, Bidanel JP. Biology and genetics of reproduction. Rothschild MF (ed) The genetics of the pig.CAB International, Wallingford.1998;313-343p. https://core.ac.uk/reader/212816670.

9. Wu F, Zhang W, Song QQ, Li H H, Xu MS, Liu GL, Zhang JZ. Association analysis of polymorphisms of $\mathrm{G}$ protein-coupled receptor 54 gene exons with reproductive traits in Jiaxing Black sows. AsianAustralas J Anim Sci. 2019;32(8):1104-1111. Doi: 10.5713/ajas.18.0827.

10. Yang WC, Tang KQ, Yu JN, Zhang CY, Zhang XX, Yang LG. Effects of MboII and BspMI polymorphisms in the gonadotropin releasing hormone receptor (GnRHR) gene on sperm quality in Holstein bulls. Mol Biol Reprod. 2011;38:3411-3415. Doi: 10.1007/s11033-0100450-2.

11. Sun LP, Du QZ, Song YP, Yu JN, Wang SJ, Sang L, Hua GH, Zhang SJ, Yang LG. Polymorphisms in luteinizing hormone receptor and hypothalamic gonadotropin-releasing hormone genes and their effects on sperm quality traits in Chinese Holstein bulls. Mol Biol Reprod. 2012;39:7117-7123. Doi: 10.1007/s11033-012-1543-x.

12. Wang G, Hao L, Li S, Zhang Y, Lv C, Shi H, Dong L, Zhang Y, Yu H, Zhang J. Effects of GnRHR polymorphisms on sperm quality in Chinese water buffalo. Anim Reprod Sci. 2017;186:37-43. Doi: 10.1016/j.anireprosci.2017.09.001

13. Wang S, Zhang Y, Cheng Y, Lu G, Yang R, Geng H, Wang C, Li H, Feng T, Liu S, Hao L. Association of SNPs in GnRH gene with sperm quality traits of Chinese water buffalo. Reprod Domest Anim. 2020;55(3):384-392. https://doi.org/10.1111/rda.13634.

14. Watson, PF. Use of Giemsastain to detect changes in the acrosome of frozen ram spermatozoa. Vet Rec. 1975;97:12-15. Doi: 10.1136/vr.97.1.12.

15. Weyrich A. Preparation of genomic DNA from mammalian sperm. Curr Prot Mol Bioly. 2012;2(13):11-13. Doi: 10.1002/0471142727.mb0213s98.

16. Milazzotto MP, Rahal P, Nichi M, Miranda-Neto T, Teixeira LA, Ferraz JBS, Eler JP, Campagnari F, and Garcia JF. New molecular variants of hypothalamus- pituitary- gonad axis genes and their association with early puberty phenotype in Bos Taurus indicus 
(Nellore). Live Stock Sci. 2008;114:274-279. https://doi.org/10.1016/j.livsci.2007.05.006.

17. Sosa ASA, Mahmoud KGhM, Eldebaky HAA, Kandiel MMM, Abou El-Roos MEA, Nawito MF. Single nucleotide polymorphisms of GnRHR gene and its relationship with reproductive performance in Egyptian buffaloes. Egypt J Vet Sci. 2016;47(1):41-50. Doi: 10.21608/ejvs.2016.1081.

18. Sanguinetti CJ, Dias Neto E, Simpson AJG. Rapid silver staining and recovery of PCR products separated on polyacrylamide gels. Biotechniques.

1994:17:915-919. https://pubmed.ncbi.nlm.nih.gov/7840973/.

19. Benbouza H, Jacquemin JM, Baudoin JP, and Mergeai G. Optimization of a reliable, fast, cheap and sensitive silver staining method to detect SSR markers in polyacrylamide gels. Biotechnol Agron Soc Environ. 2006;10:77-81. https://www.researchgate.net/publication/26433489.

20. Shoukir Y, Chardonnens D, Campana A, Sakkas D. Blastocyst development from supernumery embryos after intracytoplasmic sperm injection: A paternal influence? Hum Reprod. 1998;13:1632-1637. Doi: 10.1093/humrep/13.6.1632.

21. Mahmoud KGM, Ziada M, and Scholkamy TH. Freezability of buffalo semen in relation to its in-vitro fertilizing capacity and chromosomal picture. J Egypt Vet Med Assoc. 2004;64:239-251. https://www.semanticscholar.org/paper/.

22. Abdel Dayem AMH, Mahmoud KGM, Nawito MF, Ayoub MM, Scholkamy TH. Fertility evaluation in Egyptian buffalo bulls using zonapellucida binding and in vitro fertilization assays. Livestock Sci. 2009;122:193-198. https://doi.org/10.1016/j.livsci.2008.08.014.

23. Sanchez R, Stale T, Khanago O, Turley H, Gips H, Schill WB. Sperm selection methods for intracytoplasmic sperm injection (ICSI) and andrological patients. J Assist Reprod Gen. 1996;13:228-233. Doi: 10.1007/BF02065941.

24. García-Álvarez O, Maroto-Morales A, Ramón M, Del Olmo E, Montoro V, Dominguez-Rebolledo AE, Bisbal A, Jiménez-Rabadán P, Pérez-Guzmán MD, Soler AJ. Analysis of selected sperm by density gradient centrifugation might aid in the estimation of in vivo fertility of thawed ram spermatozoa. Therigenol. 2010;74:979-988. https://doi.org/10.1016/j.theriogenology.2010.04.027.

25. Mahmoud KGM, El-sokary AAE, Abou El-Roos MEA, Abdel-Ghaffar AE, Nawito M.Sperm characteristics in cryopreserved buffalo bull semen in relation to field fertility. Iran J Appl Anim Sci. 2013;3:777783. http://ijas.iaurasht.ac.ir/article_513585.html.

26. Barros PMH, Nichi M, Cortada CNM, Carvalho NAT, Baruselli PS, Barnabe RC, and Barnabe VH. Semen evaluation of Murrah buffalo bulls using sperm functional tests. Ital J Anim Sci. 2007;6:772-774. https://doi.org/10.4081/ijas.2007.s2.772.

27. Singh S, Bhakat M, Mohanty TK, KumarA, Gupta AK, Chakravarty AK, Singh P. Sexual behavior and its relationship with semen quality parameters in Sahiwal breeding bulls. Vet World. 2015;8(6):745-749. Doi: $10.14202 /$ vetworld.2015.745-749.

28. Moghaddam G, Pourseif MM, Rahimi AAR. Study of correlation between reaction time and refractory period (as indices of libido) with semen characteristics in ArkharMerino $\times$ Moghani and Baluchi $\times$ Moghanirams. Ital J Anim Sci. 2012;11(4):363-367. https://doi.org/10.4081/ijas.2012.e66.

29. Anzar M, Ahmad M, Nazir M, Ahmad N, Shah IH. Selection of buffalo bulls: Sexual behavior and its relationship to semen production and fertility. Theriogl. 1993;40:1187-1198. https://doi.org/10.1016/0093691X (93) 90289-H.

30. Moghaddam G, Pourseif M M and Rahimi AA. Study of correlation between reaction time and refractory period (as indices of libido) with semen characteristics in Arkhar Merinox Moghani and Baluchix Moghani rams. Ital J Anim Sci. 2012;11(4):e66. Doi.org/10.4081/ijas.2012.e66.

31. Lin CL, Ponsuksili S, Tholen E, Jennen DG, Schellander K, Wimmers K. Candidate gene markers for sperm quality and fertility of boar. Anim Reprod Sci. 2006;92:349-363. Doi: 10.1016/j.anireprosci.2005.05.023.

32. Kerekoppa R, Basavaraju M, Rao A, Geetha GR, Mukund K, Sakthivel J. Single nucleotide polymorphism identification and characterization of GnRHR gene in Bostaurus and Bosindicus cattle. Turk J Vet Anim Sci. 2015;39:10-15. Doi: 10.3906/vet-1310-47.

33. Liron JP, Prando A, Ripoli MV, Rogberg-Munoz A, Posik DM, Baldo A, Peral-Garcia P, Giovambattista G. Characterization and validation of bovine gonadotripin releasing hormone receptor (GnRHR) polymorphisms. Res Vet Sci. 2011;91:391-396. Doi: 10.1016/j.rvsc.2010.09.024

34. Habib, H N. Molecular characterization of heat shock protein 70 gene in Iraqi buffalo. Iraq $\mathrm{J}$ Vet Sci.2020;34:139-143. Doi: 10.33899/ijvs.2019.125633.1116.

\section{تعدد الأشكال الجينية لمستقبلات الهرمون المنظم لعمل

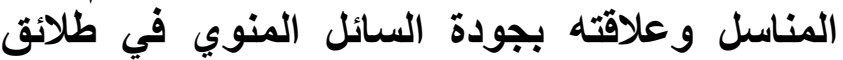

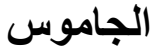

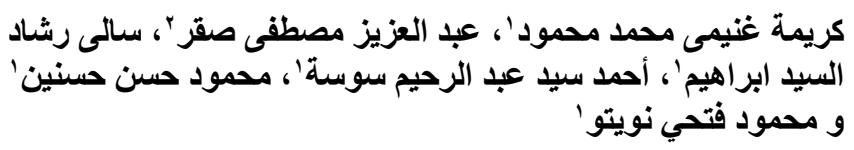

'قسم التكاثر في الحيو ان والتلقيح الاصطناعي، المركز القومي للبحوث،

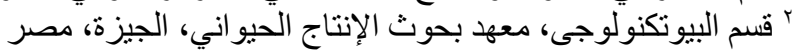

الخلاصة

تم تقييم عدد خمسون طلوقة لحجم القذفة، الحركة الفردية، تركيز وحيوية ونتو هات الحيامن وكذلك سلامة الاكروزوم. وتم تقبيم الطلائق

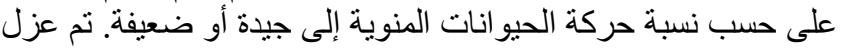

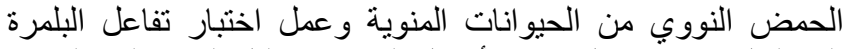

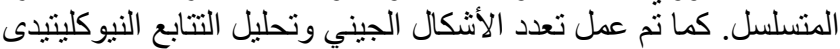

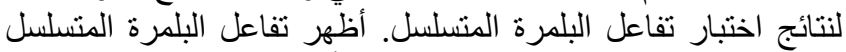

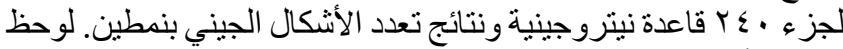

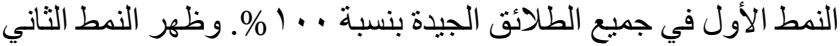

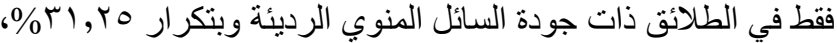
كما أظڤهر تحليل التتابع النيوكليتيدى لنتائج تفاعل البلمرة التردئل المتسلسل للنمطين تعدد أشكال النيوكليوتيدات المفردة كطفرة استبدال قاعدة في

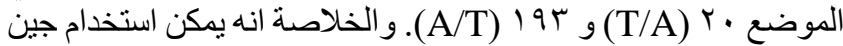
الهرمون المنظم لعمل المناسل كعلامة ور اثية تتعلق بجودة السائل المنوي الثي في طلائق الجاموس المصري نظراً للنمط الفريد في الحيوانات المنوية

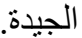

